\section{Target: MTN}

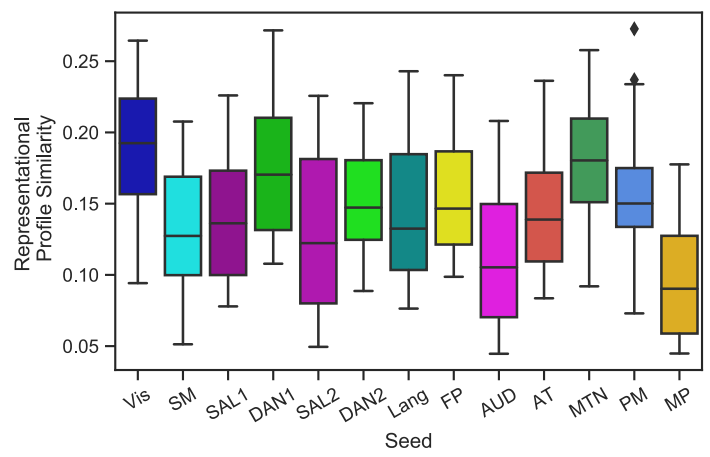

Target: PM

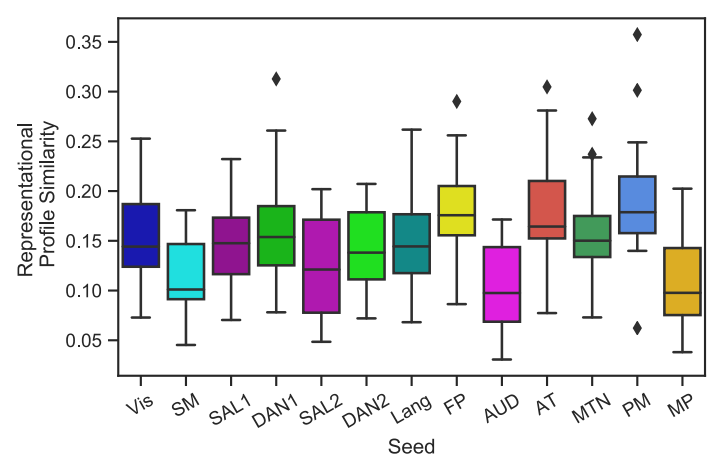

Target: AT

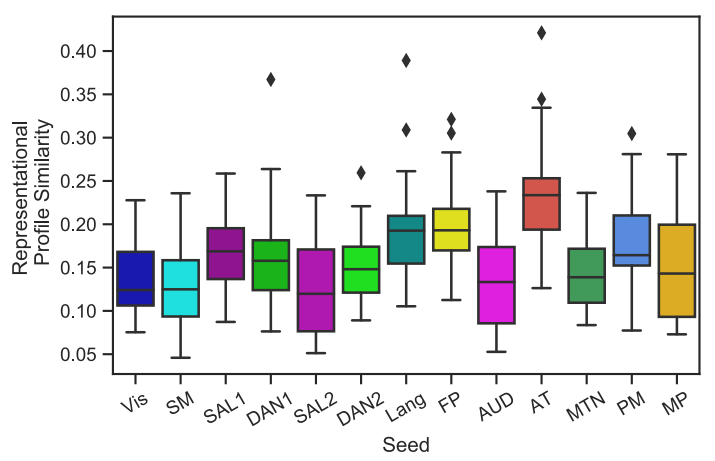

Target: MP

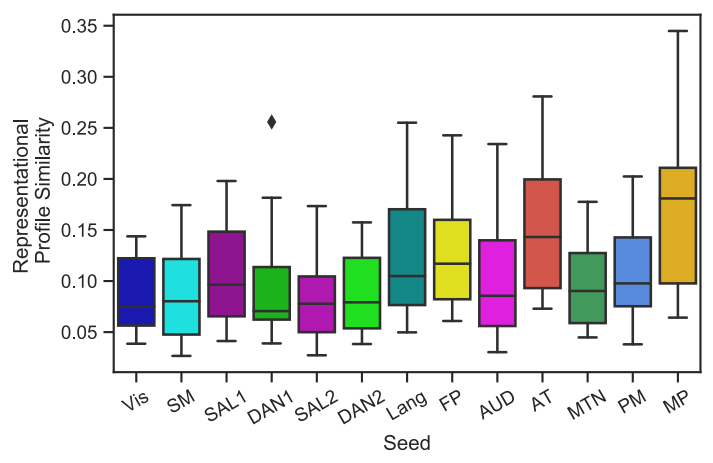

